Research Article

\title{
Implementation of a Scientific Approach Based on Local Culture
}

\author{
Kristiana Riatin *, Sulaiman, Darmiati \\ Master Program of Early Childhood Teacher Education, Universitas Lambung Mangkurat, Banjarmasin \\ 70123, Indonesia
}

Article history:

Submission September 2020

Revised October 2020

Accepted November 2020

*Corresponding author:

E-mail: sa78222007@yahoo.co.id

\begin{abstract}
Children are natural scientists by nature, and they can think and act scientifically. The scientific approach is a learning process intended in such a way that students actively build competency attitudes, knowledge, and skills in its implementation using the 2013 PAUD curriculum. Therefore, this study aims to describe the implementation of a scientific approach based on local culture. This study uses a descriptive qualitative approach with a multi-site study design with data collected through interviews, observation, and documentation in the Kartika V-9 kindergarten and Citra Indonesia kindergarten, Banjarbaru City. The validation of data is using the triangulation of sources, techniques, and time. Based on the research results, it is concluded that: (1) Planning that begins with the preparation of a program contained in the 2013 PAUD Curriculum (2) learning themes (3) the obstacles faced are the limited learning resources that can be obtained by the teacher, (4) solutions to overcome these obstacles with the help of audiovisual equipment such as LCDs with video displays and other replacement equipment. Suggestions for the institution should periodically provide parents information about learning programs implemented in schools so that the education provided is sustainable and in line with education at home through school programs, especially in introducing local culture through a scientific approach.
\end{abstract}

Keywords: Curriculum 2013 PAUD, scientific approach, local culture

\section{Introduction}

Education is the right of every citizen (Englund, 1994). The hope is that education can be enjoyed and accessed as early as possible by all Indonesians. The state's commitment that the government strives and implements a national education system that increases faith and devotion to God Almighty (Sunhaji, 2016). In the framework of implementing the education system, the government must be able to ensure equal education opportunities, increase the quality and relevance and efficiency of education management that is per the challenges of the times children will face (Kalyanpur, 2008).

The national education system, in general, has guaranteed educational opportunities throughout the nation, the quality of improvement and the relevance and efficiency of education to face current challenges and changes in life at the local, national and global levels (Mulyadi, 2017). Therefore, it is necessary to reform education as planned, directed, and sustainable (Sukriani et al., 2017). It is very important because education will help people to face their futures (Baharuddin \& Dalle, 2019).

Early Childhood Education exists as an educational institution that handles children during their golden period. The age of 0-5 years is a critical period for a child to shape his character (Rubin et al., 1999). PAUD focuses on children's potential which is very important to be developed and becomes the initial foundation

How to cite:

Riatin, K., \& Darmiaty. (2019). Implementation of a scientific approach based on local culture. Journal of K6 Education and Management, 3 (3), 350 - 360. doi: 10.11594/jk6em.03.03.07 
in shaping children's character (Salasiah, Asniwati, \& Effendi, 2018). According to Suriansyah \& Aslamiah (2011), Kindergarten Education is a form of early childhood education that has an essential role in developing children's personalities and preparing them to enter the next level of education.

A child in early childhood is a researcher (Malone, 2013). All forms of curiosity always want to be answered and proven (Krapp \& Prenzel, 2011). It is because it has become one of the characteristics of early childhood, namely, high curiosity. So, it is not surprising if they are happy to try new things at an early age or do trials of new things that they have never known.

The sensitive period or the golden age is when children begin to be sensitive to receive various stimulations and various educational efforts from their environment, whether intentional or unintentional. This sensitive period occurs when physical and psychological functions matured so that children are ready to respond and realize all developmental tasks expected to appear in their daily behavior. Not only can one aspect of development develop optimally, but all aspects of children's development such as language, cognitive, social, emotional, physical motor, and religious and moral values can all develop optimally.

Therefore, the learning process for the 2013 Curriculum is per Government Regulation Number 32 of 2013 concerning amendments to Government Regulation number 19 of 2005 concerning National Education standards, basically strengthening the previous curriculum and developing aspects of the curriculum structure, the learning process with a scientific approach (Utami et al., 2016). Each child has its uniqueness, whether due to genetic or environmental factors. Which is very influential in the way children learn. Seeing this, PAUD institutions must also have an adequate curriculum structure to facilitate their students. Fundamentally, the 2013 Curriculum for Early Childhood Education is expected to be the basis for students' preparation to be more confident in moving to a higher level of education. The curriculum is an instructional design that summarizes all the learning experiences provided for students at school. In the philosophy curriculum, values, knowledge must be integrated with educational actions (Suhaimi \& Rinawati, 2018).

The 2013 PAUD curriculum carries the development of constructivism theory, which is more flexible in its implementation but provides more space for children to develop their potential and talents. One of the peculiarities of the 2013 curriculum is to apply a scientific approach in the learning process. This approach is a learning process designed so that students are active in constructing several competencies such as attitudes, knowledge, and skills through the stages of observing, asking, gathering information, reasoning, and communicating them (Zaim, 2017). Through scientific learning, children are expected to be more critical and logical in thinking (Ann Haefner \& Zembal-Saul, 2004). Experts also mention that the introduction of scientific learning should be introduced as early as possible. It can help children recognize and understand their world and help them be involved in constructing their knowledge. Through scientific learning, all of the child's senses will be stimulated so that all children's intelligence can be explored (Leach et al., 1995).

Seeing the importance of applying a scientific approach to cultivating Core Competencies of Early Childhood as an application of the 2013 Early Childhood Education curriculum, in reality, not all PAUD institutions have implemented it. Changes in the curriculum to date are still marked as changes in curriculum documents. However, the way teachers teach has not changed so that it will impact the level of achievement of children's development that has not reached the standard level of child development achievement.

Another factor to support the development of children's learning outcomes is the ability of teachers to deliver learning materials that motivate and can coordinate children in the class (Metroyadi \& Mardhiah, 2018). The role of the teacher also does not have to be from the success of learning. As the spearhead of learning, the teacher chooses a model, learning strategies are quite suitable for learning success (Tharayil et al., 2018). The teacher's role is to help children gain the ability to communicate, 
solve problems, and resolve conflicts (Ashiabi, 2007). Activities can be planned precisely to promote cooperative behavior in the classroom and learning centers for kindergarten children. Cooperative learning can make them more creative (Suriansyah, 2011). According to Baiti, Metroyadi, \& Wahyu (2019), the role of teachers and parents is critical in children's development, especially in understanding the golden age of children as early as possible. When conducting this research, the teacher found many benefits, including the teacher being able to understand that the child will be more active when the child is directly involved in these activities. The use of new media will foster children's attention by directly training the child. Also, the use of media makes the teaching and learning process becomes more fun and makes students get involved in the learning activities (Dalle \& Mutalib, 2018). Being a teacher does not only tell the activity, but the children do it immediately so that the cultivation of the independent attitude that the teacher wants to achieve can run optimally (Safitri, Ahmad, \& Saleh, 2018).

The teacher develops learning to improve children's success by using the learning principles stated by Suriansyah \& Aslamiah (2011) that learning is done concretely. It can be seen that the child is recognized, physically, and mentally balanced.

At this time, the government is appealing to education units to carry out education that contains local wisdom. Hopefully, students will know more about their own regional culture than other regions or countries. Besides, the implementation of education with local wisdom in education units can foster children's love for their own regional culture.

Based on the background, the research will explore the implementation of the scientific approach based on local wisdom in TK Kartika V9 and TK Citra Indonesia. Both Kindergartens have implemented a scientific approach based on local wisdom through programs prepared, which are implemented in daily learning by following the government's rules to apply a scientific approach to instill core competencies in the learning process. Actually, before the application of these rules in the learning process, we have tried to involve children directly in the process of finding information and knowledge. So that with the 2013 PAUD curriculum, they will not experience any problems.

\section{Material and Methods}

This study used a qualitative descriptive approach with multi-site research design and data collection techniques through interviews, observation, and documentation-research time for one year. Data were analyzed from the research process in the field that was carried out until the end of data collection.

The objects of observation consist of educators, educational staff, parents, and learning activities. The interview object is related to how the planning is, how the implementation process is, what the obstacles are faced, and the solutions that can be made to overcome obstacles in implementing a scientific approach based on local wisdom. Observations were made directly by observing the learning process at TK Kartika V-9 and in TK Citra Indonesia, Kota Banjarbaru, with learning activities, including the facilities and infrastructure owned.

Furthermore, how are the Weekly Learning Implementation Plans, Daily Learning Implementation Plans, Standard Operational Procedures (SOP), institutional profiles, vision, mission, institutional goals, administrative structures, photos of activities, and other books used to support the 2013 PAUD curriculum with a scientific approach based on local culture?

\section{Results and Discussion}

This research was conducted in Kartika V-9 Kindergarten and Citra Indonesia Kindergarten, Banjarbaru City, based on a permit from the Head of the Early Childhood Education Study Program at the University of Lambung Mangkurat. The data obtained from the two institutions are as follows:

\section{The planning in implementing a scientific ap- proach is based on culture}

The scientific approach based on local wisdom applied in Kartika V-9 Kindergarten and Citra Indonesia Kindergarten, which is carried out through a planning process, is developed by a curriculum development team involving all 
educators, education staff, supervisors, and parents of students. All plans are arranged in a respective Education Unit Level Curriculum document. This document contains all activity plans during one lesson: learning programs and institutional programs related to each other. The implementation of all programs contained in this KTSP document is equipped with standard operating procedures so that the appropriateness of this local wisdom-based scientific approach can run as planned.

The implementation of the 2013 curriculum policy for early childhood education is stipulated by the Minister of Education and Culture Decree Number 146 of 2014 concerning the 2013 Curriculum for Early Childhood Education. Along with implementing the 2013 PAUD curriculum, the Minister of Education and Culture Regulation Number 137 of 2014 was issued, which regulates the National Standard for Early Childhood Education. The policies in the two laws have implications for developing the Education Unit Level Curriculum (KTSP PAUD), which must be developed by each PAUD level Education Unit. These two regulations contain the idea of the 2013 curriculum so that the PAUD level KTSP development team should understand both.

As stated by Hasan (2008), curriculum ideas are the most critical component of the curriculum development process. A more detailed opinion is as follows. Curriculum ideas are an essential component in the curriculum development process (Arseven, 2014). The idea of the curriculum is a formulation of the educational philosophical position adopted, the theoretical view of the curriculum concept, the curriculum model used, the concept of content, curriculum organization, curriculum design, curriculum document design, the position of students in learning (Edelson, Gordin, \& Pea, 1999).

Curriculum ideas must be precise because they become the basis and foundation for the development of various components of the curriculum document. This opinion shows that curriculum development curriculum ideas need to be understood by the development team (McGadden \& Roehrig, 2017) so that the development of curriculum documents that are prepared reflects continuity with curriculum ideas. Without clarity of curriculum ideas, it is possible to discontinue the idea and the curriculum document. According to Hasan (2008), the clarity of curriculum ideas is constructive for the development team in constructing curriculum documents.

\section{The implementation process in a scientific approach based on local culture}

The scientific approach based on local wisdom implemented by these two sites has similarities in the implementation process. The stages of the scientific approach applied in the learning process using 5 stages, namely: observing, asking (questioning), trying (experimenting), processing data or information followed by analyzing, reasoning (associating), and concluding, presenting data or information (communicating) and creating and forming networks (networking) (In'am \& Hajar, 2017).

The learning process using a scientific approach is directed so that students can formulate problems (by asking many questions), not just solving problems by answering them (Chin \& Brown, 2002). The learning process is expected to train analytical thinking (students are taught how to make decisions) not mechanistic thinking (routinely only listening and memorizing (Majid, 2014).

The learning objective using a scientific approach is to develop student character (Puente et al., 2013). It is also to improve students' thinking abilities so that they can solve any problems they face and have excellent learning outcomes (Sudirman, Fatimah, \& Jupri, 2017).

Two important things that need to be considered in the application of center learning are: first, the intensity of children's play and how to play prepared by the teacher to support the child's play experience (Maimunah, Aslamiah, \& Suriansyah. A, 2018). Learning media as a means of implementing the scientific approach TK Kartika V-9 and TK Citra Indonesia both use local wisdom-based media both from the surrounding environment and media from used goods found around the school environment. The support program as a reinforcement for the concept of the two sites' learning theme carries out the top theme activities through visits to learning resource places for children. 
The implementation of the scientific approach can also be carried out in opening or core activities. The five things can also be out of order, depending on the learning conditions. According to the findings in the field, this opinion is in line with the implementation of the scientific approach carried out in Kartika V-9 Kindergarten and Citra Indonesia Kindergarten. The stages of the Scientific approach implemented are listed in the KTSP document, which in general are carried out in the learning process, as described below:

a. Observe

The method of observing prioritizes the meaningful learning process. The method of observing is beneficial for fulfilling students' curiosity so that the learning process has a significant meaning. With the observation method, students find the fact that there is a relationship between the object analyzed and the teacher's learning material.

\section{b. Asking}

Asking is a thinking process driven by children's curiosity about an object or event (Spektor-Levy, Baruch, \& \& Mevarech, 2013). Children like to ask questions. Children will continue to ask questions until their curiosity is answered. Often parents and teachers break children's curiosity by thinking that children are talkative. Asking questions is a process of exploring new knowledge (Olsher \& Kantor, 2012). Teachers can help children to formulate questions they want to know. The learning activity of questioning is done by asking questions about the information that is not understood from what is observed or questions to get additional information about what is observed.

\section{c. Gather information}

The activity of gathering information is a follow-up to asking questions. This activity is carried out by exploring and gathering information from various sources in various ways. Students can read various sources, pay attention to phenomena or objects that are more accurate, or even carry out experiments.

d. Reasoning

In the activities of associating / processing information, there are reasoning activities within the framework of the learning process with the scientific approach adopted in the 2013 curriculum to illustrate that teachers and students are active actors. The reasoning is a logical and systematic thinking process on empirical facts that can be observed to obtain conclusions in the form of knowledge (Kovács \& Spens, 2005).

\section{e. Communicate}

In the scientific approach, the teacher is expected to provide students with opportunities to communicate what they have learned. This activity can be done through writing down or telling what was found in the activities of seeking information, associating, and finding patterns.

\section{Constraints faced in implementing a scien- tific approach based on local culture}

The obstacles faced by these two sites are in terms of students, from teachers, and technical constraints. Constraints in applying the scientific approach that came from students of these two sites were that students had a lack of interest in the media, which was the focus of observation so that the process of the next stages did not work correctly.

The lack of interest of these students causes children not to ask questions and not respond to questions submitted by the teacher, which also impacts the information gathering stage. The information that is expected to develop from the questions that arise from students is not optimal.

Lack of information that can be digested by students also has an impact on the reasoning process of students (Plank \& Jordan, 2001). Kartika V-9 Kindergarten and Citra Indonesia Kindergarten also experience the same obstacles the teachers face, namely the limitations of certain media that are difficult to obtain so that they do not support the implementation of the scientific approach. The technical issues found by these two sites were obstacles in the implementation of supporting activities for the application of the scientific approach, namely in the implementation of the theme program or field visit activities. These technical constraints are in the form of lack of weather support or not 
supporting the place to be visited, distance, and means of transportation.

From the findings in the field, TK Kartika V9 and TK Cinta Indonesia both have inhibiting factors in implementing the scientific approach. Inhibiting factors found in the field are students who have different characteristics and individual abilities (Gilakjani, 2011). Students who are enthusiastic and have high motivation will be very fast in following and carrying out learning activities (Baya'a \& Daher, 2009). On the other hand, students who lack motivation and are less attractive in presenting learning that day will experience difficulties in carrying out learning activities (Liu \& Chu, 2010). This situation creates obstacles in implementing thematic learning with a scientific approach. Moreover, here it is demanded that more active students find themselves in finding out. Another inhibiting factor is the limited space for children to carry out activities because the learning space is not too ample so that students are less free in their activities (Orion \& Hofstein, 1994).

\section{Solutions that can be made to overcome ob- stacles in implementing a scientific approach based on local culture}

From the obstacles faced above, TK Kartika V-9 and TK Citra Indonesia have the same in taking steps to solve it. Overcoming the obstacles faced by the teacher in dealing with students who are less interested or less motivated in the observation media that the teacher has prepared, the teacher reads the storybook according to the theme or invites the child to watch videos through laptop media about the objects to be observed. Usually, children begin to be motivated after knowing the benefits or importance of the observed media for students
(Bicen \& Kocakoyun, 2018). If the efforts made are still not fostering students' interest, the teacher will change the focus of other observations the next day.

The solution taken is to overcome teacher constraints in providing instructional media, which will be the focus of observation, teachers in advance of trying to find information on online media, or asking for help from parents of students who can help provide learning media. If the media in question is not found, then the focus of the observation will be replaced with other objects/media, but they still do not leave the theme. Another solution is taken by the institution to overcome technical obstacles. The curriculum development team coordinates with parents and managers to discuss whether to stay on schedule or wait until environmental conditions are implemented.

From the problems that have been expressed above, solutions can be made to overcome obstacles in implementing a scientific approach based on local wisdom of Kartika V-9 Kindergarten and Citra Indonesia Kindergarten, the teachers are working even harder to create engaging, more creative activities in pouring ideas into learning designs, more control over the class, create a happy and enjoyable play environment, create a play environment that attracts children's interests, and provide tools and materials that encourage children's interest in playing. Collaborating with all the institution members to find solutions to overcome the obstacles they face is a wise step so that institutions and parents have the same mission in achieving educational goals.

The data obtained from the two institutions are compared in table 1 as follows:

Table 1. Comparison of finding from 1 and site 2

\begin{tabular}{|l|l|l|l|}
\hline No & Research Focus & Data of Site 1 & Data of Site 2 \\
\hline 1. & How to plan the implementation of a & -The planning of implementing & -Planning for the imple- \\
& scientific approach based on local wis- \\
dom TK Kartika V-9 and TK Indonesia & $\begin{array}{l}\text { a scientific approach based on } \\
\text { local wisdom is designed } \\
\text { through a working meeting to } \\
\text { Citra Banjarbaru } \\
\text { To be continued... }\end{array}$ & $\begin{array}{l}\text { approach based on local } \\
\text { wisdom is arranged in a } \\
\text { ment. }\end{array}$ & \\
\hline
\end{tabular}




\begin{tabular}{|c|c|c|c|}
\hline & & & $\begin{array}{l}\text { workshop on curricu- } \\
\text { lum document prepara- } \\
\text { tion }\end{array}$ \\
\hline & & $\begin{array}{l}\text {-Preparation of curric-ulum } \\
\text { document plan-ning by involv- } \\
\text { ing su-pervisors, curriculum } \\
\text { compilation team, teaching } \\
\text { staff, educa-tion personnel, } \\
\text { and committees }\end{array}$ & $\begin{array}{l}\text {-Preparation of curricu- } \\
\text { lum documents accom- } \\
\text { panied by a competent } \\
\text { resource in the field of } \\
\text { curriculum }\end{array}$ \\
\hline & & & $\begin{array}{l}\text {-Preparation of curricu- } \\
\text { lum documents involv- } \\
\text { ing all prin-cipal teach- } \\
\text { ers and committees }\end{array}$ \\
\hline \multirow[t]{4}{*}{2.} & \multirow[t]{4}{*}{$\begin{array}{l}\text { How is the process of implementation a } \\
\text { scientific approach based on local wis- } \\
\text { dom Kartika V-9 Kindergarten and } \\
\text { Citra Indonesia Kindergarten, Ban- } \\
\text { jarbaru? }\end{array}$} & $\begin{array}{l}\text { - The process of im-plement- } \\
\text { ing a scien-tific approach } \\
\text { based on local wisdom us-ing } \\
\text { the Learning model beyond } \\
\text { center cycle time }\end{array}$ & $\begin{array}{l}\text { - The process of imple- } \\
\text { menting a scientific ap- } \\
\text { proach based on local } \\
\text { wisdom using the } \\
\text { Learn-ing model be- } \\
\text { yond center circle time }\end{array}$ \\
\hline & & $\begin{array}{l}\text { - The process of im-plement- } \\
\text { ing a scien-tific approach } \\
\text { based on local wisdom be-gins } \\
\text { with the ar-rangement of the } \\
\text { Play Environment. }\end{array}$ & $\begin{array}{l}\text { - The process of imple- } \\
\text { menting a scientific ap- } \\
\text { proach based on local } \\
\text { wisdom begins with the } \\
\text { arrangement of the Play } \\
\text { Environment. }\end{array}$ \\
\hline & & $\begin{array}{l}\text { - Scientific approach: local } \\
\text { wisdom-based scientific using } \\
\text { five stages }\end{array}$ & $\begin{array}{l}\text { - Scientific approach: } \\
\text { local wisdom-based sci- } \\
\text { entific using five stages }\end{array}$ \\
\hline & & $\begin{array}{l}\text { - Learning model be-yond } \\
\text { center circle time imple- } \\
\text { mented with system Moving } \\
\text { Class. }\end{array}$ & $\begin{array}{l}\text { - Learning model be- } \\
\text { yond center circle time } \\
\text { imple-mented with } \\
\text { Moving Class system. }\end{array}$ \\
\hline \multirow[t]{4}{*}{3.} & \multirow[t]{4}{*}{$\begin{array}{l}\text { Constraints faced in implementing the } \\
\text { scientific approach based on local wis- } \\
\text { dom TK Kartika V-9 and TK Indonesia } \\
\text { Citra Banjarbaru. }\end{array}$} & $\begin{array}{l}\text { - Limited availability of media } \\
\text { to support the implementation } \\
\text { of a scientific ap-proach based } \\
\text { on lo-cal wisdom }\end{array}$ & $\begin{array}{l}\text { - Limited availability of } \\
\text { media to support the } \\
\text { im-plementation of a } \\
\text { scien-tific approach } \\
\text { based on local wisdom }\end{array}$ \\
\hline & & $\begin{array}{l}\text { - Differences in the ability of } \\
\text { students }\end{array}$ & $\begin{array}{l}\text { - Differences in the } \\
\text { ability of students }\end{array}$ \\
\hline & & $\begin{array}{l}\text { - The teacher's ability to im- } \\
\text { plement a scien-tific approach } \\
\text { based on local wisdom }\end{array}$ & $\begin{array}{l}\text { - The teacher's ability } \\
\text { to implement a scien- } \\
\text { tific approach based on } \\
\text { local wisdom }\end{array}$ \\
\hline & & - Parental support & $\begin{array}{l}\text { - Enough children in } \\
\text { each class }\end{array}$ \\
\hline
\end{tabular}




\begin{tabular}{|c|c|c|c|}
\hline & & & $\begin{array}{l}\text { - Classrooms that do } \\
\text { not match the number } \\
\text { of chil-dren }\end{array}$ \\
\hline & & & - Parental support \\
\hline \multirow[t]{7}{*}{4.} & \multirow[t]{7}{*}{$\begin{array}{l}\text { Solutions can be done to overcome ob- } \\
\text { stacles in implementing a scientific ap- } \\
\text { proach based on local wisdom Kartika } \\
\text { V-9 Kindergarten and Citra Indonesia } \\
\text { Kindergarten, Banjarbaru. }\end{array}$} & - Provide replacement media & $\begin{array}{l}\text { - Limited availability of } \\
\text { me-dia to support the } \\
\text { imple-mentation of a } \\
\text { scientific approach } \\
\text { based on local wisdom }\end{array}$ \\
\hline & & $\begin{array}{l}\text { - Change the focus of the } \\
\text { theme }\end{array}$ & $\begin{array}{l}\text { - Differences in the } \\
\text { ability of students }\end{array}$ \\
\hline & & - Enabling additional methods & $\begin{array}{l}\text { - Grouping children } \\
\text { into small groups }\end{array}$ \\
\hline & & - Providing information early & $\begin{array}{l}\text { - Using the yard and } \\
\text { ter-race as an alterna- } \\
\text { tive place to play }\end{array}$ \\
\hline & & $\begin{array}{l}\text { - Improve coordination be- } \\
\text { tween parents }\end{array}$ & $\begin{array}{l}\text { - Using the yard and } \\
\text { ter-race as an alterna- } \\
\text { tive place to play }\end{array}$ \\
\hline & & $\begin{array}{l}\text { - Improve the coordina-tion of } \\
\text { parents and in-stitutions }\end{array}$ & $\begin{array}{l}\text { - The teacher's ability } \\
\text { to im-plement a scien- } \\
\text { tific ap-proach based on } \\
\text { local wis-dom }\end{array}$ \\
\hline & & & -Parental support \\
\hline
\end{tabular}

\section{Conclusion and Recommendation}

Based on the discussion about the implementation of the character-based scientific approach in Kartika V-9 Kindergarten and Citra Indonesia Kindergarten, the following conclusions are obtained:

1. The curriculum document owned is the basis for the implementation guide in the learning process compiled at the end of the school year's work meeting. A result of the formulation of the curriculum compilation team consisting of elements of kindergarten heads, teaching staff and education, and involving school committees who have successfully planned and authorized by their respective supervisors. Systematically and in detail, the formulation of planning for learning activities and supporting learning activities is arranged in the form of a curriculum doc- ument; namely, the contents are contained in Part II Document I and Part III Document II.

2. The stages in implementing a scientific approach based on local wisdom are carried out in the process of learning activities and supporting activities outside of learning activities. By visiting learning resource places, the center teacher starts from preparing learning media, which is carried out before the learning process begins, called a footing play environment by applying the scientific approach stages. The five stages, namely observing, asking questions, gathering information, reasoning, and communicating as well as through self-development activities, learning regional dances, singing regional songs, introducing regional language vocabulary, playing traditional games, getting to know traditional music, 
introducing traditional foods and drinks through complementary feeding activities.

3. Constraints of implementing a scientific approach based on local wisdom in learning based on the 2013 PAUD curriculum include limitations in obtaining media per the predetermined theme and the provision of learning media that is less attractive to children so that it has an impact on children's interest and enthusiasm. There are differences in children's abilities in participating in the learning process, teachers' ability to develop a scientific approach, the size of the less supportive classrooms, and a large number of students in each class-visits learning resource place the constraints of technical factors in the field. Weather factors do not support for visits in the open and the support factor of parents in the lack of fulfilling children's obligations and support for mentoring in certain activities outside of school that have limited time.

4. Overcoming the obstacles faced, in essence, lies in the need to establish communication and coordination between parents and schools and coordination between parents.

The author presents several suggestions as a contribution of thought in the hope that there are benefits that can be taken to further improve the quality of learning, especially by implementing a scientific approach based on local wisdom, namely:

1. For the Education Unit

- Increase the competence of educators in managing learning by participating in activities that add insight, such as seminars, workshops, symposia, or training, both independently and organized by the government.

- Facilitating the form of learning tools and allocation of funds to support the implementation of a specific approach for the better.

2. For Educators

- It is further increasing the ability to design and manage to learn, especially in applying a scientific approach based on local wisdom through seminars, workshops, workshops, and training.

- Increasing the ability to create more creative learning media fosters the interest of students in playing activities.

3. For parents, further increase support for education units and teachers, especially in supporting the implementation of a scientific approach based on local activities, can impact students' ability in the learning process.

\section{Acknowledgment}

Thanks to the head of the program, the secretariat, and the lecturers of the Master of Teacher Education Program in Early Childhood Education at the University of Lambung Mangkurat, Banjarmasin, who have provided input and suggestions for writing this article. Furthermore, thanks to the educators and education staff at TK Kartika V-9 dan TK Citra Indonesia Kota Banjarbaru, who have helped with the smooth running. May we all always be in the Blessing of Allah SWT.

\section{References}

Ann Haefner, L., \& Zembal-Saul, C. (2004). Learning by doing? Prospective elementary teachers' developing understandings of scientific inquiry and science teaching and learning. International Journal of Science Education , 26(13), 1653-1674. doi:10.1080/0950069042000230709

Arseven, A. (2014). The Reggio Emilia approach and curriculum development process. International Journal of Academic Research, 6(1), 166-171. doi:10.7813/2075-4124.2014/6$1 /$ B.23

Ashiabi, G. S. (2007). Play in the preschool classroom: Its socioemotional significance and the teacher's role in play. Early Childhood Education Journal, 35(2), 199-207. doi:10.1007/s10643-007-0165-8

Baharuddin, B., \& Dalle, J. (2019). Transforming Learning Spaces for Elementary School Children with Special Needs. Journal of Social Studies Education Research, 10(2), 344-365.

Baiti, N., Metroyadi, \& Wahyu. (2019). Parenting, socioeconomic, and communication between parents towards children's language skills. $j-K 6 E M, 2(1), 1-11$.

Baya'a, N., \& Daher, W. (2009). Learning Mathematics in an Authentic Mobile Environment: The Perceptions of 
Students. International Journal of Interactive Mobile Technologies, 3(1), 6-14. doi:10.3991/ijim.v3s1.813

Bicen, H., \& Kocakoyun, S. (2018). Perceptions of Students for Gamification Approach: Kahoot as a Case Study. International Journal of Emerging Technologies in Learning (iJET), 13(2), 72-93. doi:10.3991/ijet.v13i02.7467

Chin, C., \& Brown, D. E. (2002). Student-generated questions: A meaningful aspect of learning in science. International Journal of Science Education, 24(5), 521-549. doi:10.1080/09500690110095249

Dalle, J., \& Mutalib, A. A. (2018). The impact of technologies in teaching interaction design. Journal of Advanced Research in Dynamical and Control Systems, 4(special issue), 17791783.

Edelson, D. C., Gordin, D. N., \& \& Pea, R. D. (1999). Addressing the Challenges of Inquiry-Based Learning Through Technology and Curriculum Design. Journal of the Learning Sciences, 8(3-4), 391-450. doi:10.1080/10508406.1999.9672075

Englund, T. (1994). Education as a citizenship right-a concept in transition: Sweden related to other Western democracies and political philosophy. Journal of Curriculum Studies, 26(4), 383-399. doi:10.1080/0022027940260403

Gilakjani, A. P. (2011). A Study of Factors Affecting EFL Learners' English Pronunciation Learning and the Strategies for Instruction. International Journal of Humanities and Social Science, 2(3), 119-128.

Hasan, S. (2008). Curriculum evaluation. Bandung: PT Remaja Rosdakarya.

In'am, A., \& Hajar, S. (2017). Learning Geometry through Discovery Learning Using a Scientific Approach. International Journal of Instruction, 10(1), 55-70.

Kalyanpur, M. (2008). Equality, quality and quantity: challenges in inclusive education policy and service provision in India. International Journal of Inclusive Education, 12(3), 243262. doi: $10.1080 / 13603110601103162$

Kovács, G., \& Spens, K. M. (2005). Abductive reasoning in logistics research. International Journal of Physical Distribution \& Logistics Management, 35(2), $132 \quad$ - 144. doi:10.1108/09600030510590318

Krapp, A., \& Prenzel, M. (2011). Research on Interest in Science: Theories, Methods and Findings. International Journal of Science Education, 33(1), 27-50. doi:10.1080/09500693.2010.518645

Leach, J., Driver, R., Scott, P., \& Wood-Robinson, C. (1995). Children's ideas about ecology 1: theoretical background, design and methodology. International Journal of Science Education, $17(6)$, doi:10.1080/0950069950170604

Liu, T.-Y., \& Chu, Y.-L. (2010). Using ubiquitous games in an English listening and speaking course: Impact on learning outcomes and motivation. Computers \& Education, 55(2), 630-643. doi:10.1016/j.compedu.2010.02.023

Maimunah, Aslamiah, \& Suriansyah. A. (2018). The Integration of Sentra-Based Learning in Involvement of Family Pogram at Early Childhood in Developing Character Building (Multy Case At PAUD Mawaddah and PAUD Alam Berbasis karakter Sayang Ibu Banjarmasin, Indonesia). European Journal of Education Studies, 5(7), 49-63.

Majid, A. (2014). Learning strategies. Bandung: PT Remaja Rosdakarya.

Malone, K. (2013). "The future lies in our hands": children as researchers and environmental change agents in designing a child-friendly neighbourhood. The International Journal of Justice and Sustainability, 18(3), 372-395. doi:10.1080/13549839.2012.719020

McFadden, R. J., Roehrig, \& H., G. (2017). Exploring teacher design team endeavors while creating an elementary-focused STEM-integrated curriculum. International Journal of STEM Education, 4(21). doi:10.1186/s40594-017-0084-1

Metroyadi \& Mardhiah, A. (2018). Efforts to Develop Children Fine Motor Skills Through Sticking Picture Properly By Using Combination of Explicit Instruction Model And Assignment Media Utilizing Natural Materials. J-K6EM, 1, 22,64-70.

Mulyadi, A. W. (2017). Policy of Inclusive Education for Education for All in Indonesia. Policy \& Governance Review, 1(3), 201212. doi:10.30589/pgr.v1i3.57

Olsher, G., \& Kantor, I.-D. (2012). Asking Questions as a Key Strategy in Guiding a Novice Teacher: A self-study. Studying Teacher Education, 8(2), 157-168. doi:10.1080/17425964.2012.692988

Orion, N., \& Hofstein, A. (1994). Factors that influence learning during a scientific field trip in a natural environment. Journal of Research in Science Teaching, 31(10), 10971119. doi:10.1002/tea.3660311005

Plank, S. B., \& Jordan, W. J. (2001). Effects of Information, Guidance, and Actions on Postsecondary Destinations: A Study of Talent Loss. American Educational Research Journal, 38(4), 947-979. doi:10.3102/00028312038004947

Puente, S. M. G., Eijck, M-v., \& Jochems, W. (2013). A sampled literature review of design-based learning approaches: a search for key characteristics. International Journal of Technology and Design Education , 23, 717-732. doi:10.1007/s10798-012-9212-x

Rubin, K. H., Nelson, L. J., Hastings, P., \& Asendorpf, J. (1999). The Transaction between Parents' Perceptions of their Children's Shyness and their Parenting Styles. International Journal of Behavioral Development, 23(4), 937-957. doi:10.1080/016502599383612 
Safitri, M. E., Ahmad, K., \& Saleh, M. (2018). Development Of Child Independence Through Model Picture and Picture, Examples Non Examples Model and Practical Method Directly Activities of Learning Practical Life In Group B Kasih Ibu Kindergarten, Banjarmasin, Indonesia. European Journal of Education Studies, 5(7), 36-48.

Salasiah, Asniwati, \& Effendi, R. (2018). Instilling Character Values in Early Childhood in The Perspective of Curriculum and Parenting (Multi-Site Study in PAUD Islam Sabilal Muhtadin and PAUD Mawaddah, Banjarmasin, Indonesia). European Journal of Education Studies, 5 (7), 41.

Spektor-Levy, O., Baruch, Y. K., \& \& Mevarech, Z. (2013). Science and Scientific Curiosity in Pre-school-The teacher's point of view. International Journal of Science Education, 35(13), 2226-2253. doi:10.1080/09500693.2011.631608

Sudirman, M., Fatimah, S., \& Jupri, A. (2017). Improving Problem Solving Skill and Self Regulated Learning of Senior High School Students through Scientific Approach using Quantum Learning Strategy. International Journal of Science and Applied Science: Conference Series, 2(1), 249255. doi:10.20961/ijsascs.v2i1.16720

Suhaimi \& Rinawati, Y. (2018). Management of Character Education Curriculum at Vocational High School 2 Kandangan. Advances in Social Science. Educational and Humanities Research, 272-274.
Sukriani, Huda A.Y, M., Arifin, I., \& Suriansyah, A. (2017). The Implementation of The Islamic Schools Resources Total Quality Management in Banjarmasin, Indonesia. Journal of Social Sciences (COES\&RJ-JSS), 6 (1), 125-138.

Sunhaji. (2016). Teaching Model of Integrated Learning in the Islamic Religious Education of Rasise the Faith and Devotion of the Students of State's Senior Secondary Schools in Purwokerto City. European Journal of Social Sciences, 53(4), 317-325.

Suriansyah, A. (2011). Fundamentals of Education. Banjarmasin: Comdes.

Suriansyah, A., \& Aslamiah. (2011). Early Childhood Learning Strategies. Banjarmasin: Comdes.

Tharayil, S., Borrego, M., Prince, M., Nguyen, K. A., Shekhar, P., Finelli, C. J., \& \& Waters, C. (2018). Strategies to mitigate student resistance to active learning. International Journal of STEM Education, 5(7). doi:10.1186/s40594-018-0102-y

Utami, B., Saputro, S., Ashadi, \& Masykuri, M. (2016). Scientific literacy in science lesson. Prosiding ICTTE FKIP UNS 2015. 1, pp. 125-133. Surakarta: FKIP UNS.

Zaim, M. (2017). Implementing Scientific Approach to Teach English at Senior High School in Indonesia. Asian Social Science, 13(2), 33-40. 